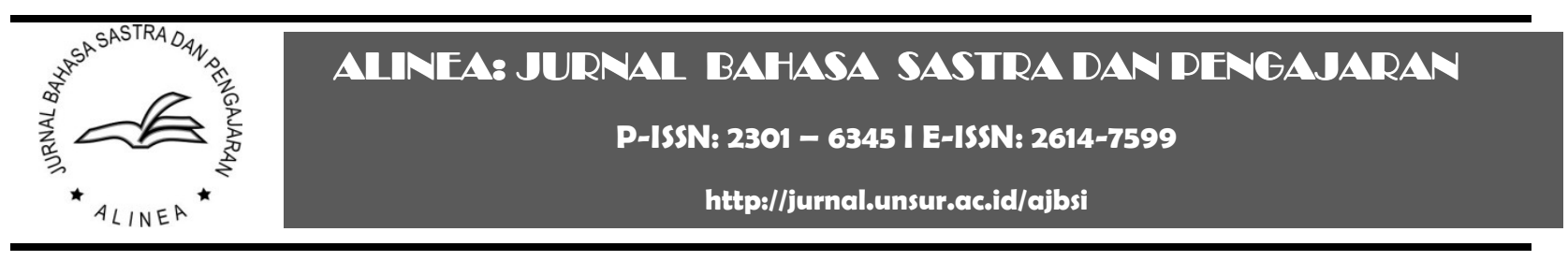

\title{
PENGGUNAAN MODEL PICTURE AND PICTURE DALAM PEMBELAJARAN MENULIS CERPEN
}

\author{
Nurvani Fitriawati Musyafa \\ Universitas Suryakancana Cianjur, Indonesia
}

Riwayat artikel:

Dikirim: 26 Juni 2019

Direvisi: 5 Nopember 2019

Diterima: 16 Januari 2020

Diterbitkan: 30 April 2020

$\overline{\text { Katakunci: }}$

cerpen

menulis

picture and picture

Alamat surat

nurvanifitriawatimusyafa@gmail.com

\begin{abstract}
Abstrak:
Artikel ini membahas efektivitas model pembelajaran picture and picture dalam meningkatkan keterampilan menulis cerita pendek. Metode yang digunakan adalah metode eksperimen dengan Posttest Design Group Control Only. Teknik yang digunakan adalah tes dan angket. Populasi kelas XI SMK Pasundan 1 Cianjur. Hasil ini menunjukkan bahwa model pembelajaran picture and picture efektif dan dikategorikan dengan baik untuk meningkatkan kemampuan menulis cerita pendek. Ditunjukkan pada kemampuan peserta didik kelas eksperimen yang diberi (perlakuan) memiliki nilai lebih tinggi dengan nilai (posttest) 72,38. Sedangkan kelas kontrol yang tidak diberikan (perlakuan) menghasilkan nilai (posttest) 64,43, dari hasil tes kelas memiliki nilai perbedaan 19,66. Dan jumlah jawaban kuesioner yang telah digunakan untuk peserta didik hampir $73 \%$ merasa bahwa model gambar difasilitasi pada penulisan, dan dianggap bahwa kegiatan menulis cerita pendek sangat menarik untuk dipelajari.
\end{abstract}

\begin{abstract}
:
This article discusses the effectiveness of picture and picture learning model in improving short story writing skills. The method used was experimental with Post test Design Group Control Only. The techniques used were test and questionnaire. The population was Class XI of SMK Pasundan 1 Cianjur. The results indicate that the picture and picture learning model is effective and well categorized to improve the ability to write short story. It is shown by the ability of experimental class students who were given (treatment) has higher score with the score (post test) of 72.38. While the control class that was not given (treatment) obtained score (post test) of 64.43, the result shows score difference of 19.66. And the number of questionnaire shows that almost $73 \%$ of students feel that picture model is facilitated in writing, and it is considered that the activity of writing short story is very interesting to learn.
\end{abstract}

\section{PENDAHULUAN}

Mata pelajaran bahasa Indonesia mencakup empat keterampilan berbahasa yang perlu dikuasai oleh peserta didik yaitu keterampilan berbicara, keterampilan membaca, dan keterampilan menulis. Keterampilan berbahasa tersebut perlu dikuasai oleh peserta didik.

Keretampilan menulis seringkali sulit dikuasai, karena dalam menulis membutuhkan wawasan yang luas mengenai materi yang akan disampaikan serta perlu kepiawan dalam menyampaikan gagasan atau informasi yang akan dituangkan ke dalam sebuah tulisan, dengan menggunakan bahasa sebagai medianya. Keterampilan menulis tidak datang secara tiba-tiba, tetapi melalui proses belajar, dan berlatih secara terus menerus.

Sebagaimana diangkapkan Dalman (2014: 3) bahwa menulis merupakan suatu kegiatan komunikasi berupa penyampaian pesan (informasi) secara tertulis kepada pihak lain dengan menggunakan tulisan sebagai alat atau medianya (Dalman). 
Kegiatan menulis memang beragam, salah satunya adalah kegiatan menulis cerita pendek. Menurut Jakob Sumardjo (2007) cerpen merupakan cerita yang membatasi diri dalam membahas salah satu unsur fiksi dalam aspeknya yang terkecil (Sumardjo). Kependekan sebuah cerita pendek bukan karena bentuknya yang jauh lebih pendek dari novel, tetapi karena aspek masalahnya yang sangat dibatasi. Belajar menulis cerpen diharapkan mampu menjadikan peserta didik lebih kreatif dalam menuangkan gagasan atau idenya secara runtut dengan isi yang tepat. Oleh karena itu, kemampuan menulis memiliki kedudukan paling tinggi diantara keterampilan lainnya.

Berdasarkan studi pendahuluan di SMK Pasundan 1 Cianjur, terdapat beberapa hambatan yang berhubungan dengan kurangnya minat peserta didik dalam menulis (1) memiliki ide cemerlang tetapi sulit menuangan ke dalam sebuah tulisan sehingga peserta didik merasa kehilangan ide saat tengah-tengah penceritaan, (2) kesulitan dalam memilih kata (diksi) dan gaya bahasa untuk dijadikan sebuah tulisan yang sesuai dengan topik yang dimaksud, (3) kurangnya kesadaran pentingnya menulis, dan (4) penggunaan model pembelajaran yang konvesional atau metode ceramah, sehingga peserta didik pasif dan hanya menerima materi yang diberikan pendidik.

Apabila kendala-kendala tersebut dibiarkan, peserta didik akan terus merasa kesulitan dalam menulis. Dengan demikian diharapkan pendidik bahasa Indonesia berupaya mencari solusi yang dapat membantu peserta didik menjadi gemar menulis. Karena terkadang tidak semua model cocok digunakan pada setiap pembelajaran, sehingga hal tersebut perlu disesuikan dengan tingkat pengetahuan, dan tingkat kemampuan peserta didik.

Berdasarkan hal tersebut, penelitian akan dilakukan secara mendalam tepatnya dalam bidang menulis, dan khususnya menulis cerita pendek. Selain itu, sebuah model pembelajaran diterapkan untuk membantu peserta didik dalam mengembangkan dan meningkatkan keterampilan menulis, model yang digunakan dalam penelitian ini adalah model pembelajaran picture and picture. Model pembelajaran ini merupakan pembelajaran yang kooperatif secara sadar dan sistematis mengembangkan interaksi dengan menggunakaan suatu gambar. Pada model ini juga peserta didik akan berperan aktif, inovatif, kreatif, dan menyenangkan serta tidak akan jenuh ataupun membosankan terhadap proses pembelajaran tersebut.

Penelitian mengenai penggunaan model pembelajaran picture and picture sudah pernah dilakukan oleh Riris Saniati, dkk. (2018) berdasarkan hasil penelitian yang telah dilakukan, terdapat pengaruh yang positif penggunaan model pembelajaran picture and picture terhadap motivasi belajar peserta didik dalam menulis cerpen di kelas XI SMK Negeri 1 Puring Kebumen dengan nilai rata-rata yang lebih tinggi diperoleh kelompok eksperimen 78,62, sedangkan kelompok kontrol 77,75. Model picture and picture efektif digunakan karena menghasilkan nilai yang baik setelah model pembelajaran diberikan (Saniati et al.). Selanjutnya, penelitian Anggi Pratiwi, dkk (2017:8) penggunaan model pembelajaran picture and picture di kelas VIII/B MTS Negeri Sijenjang terdapat pengaruh hasil keterampilan menulis berita peserta didik diperoleh data persentase terdapat 22 siswa mendapat predikat nilai baik sekali dengan persentase $61,11 \%$, terdapat 5 siswa mendapat predikat baik dengan persentase 13,89\%, terdapat 5 siswa mendapat predikat nilai kurang dengan persentase $13,89 \%$ dan 4 siswa mendapat predikat nilai gagal dengan persentase $11,11 \%$, jumlah persentase keseluruhan 100\%. Dengan jumlah keseluruhan 259. Sedangkan jumlah siswa yang mendapat predikat baik sekali sebanyak 22 orang siswa, 5 orang siswa yang mendapat predikat baik, 5 orang siswa yang mendapat predikat kurang dan 4 orang siswa mendapat predikat gagal. Dengan nilai rata-rata keseluruhan 72 predikat yang diperoleh adalah baik (Pratiwi et al.). 
Nur Puspitasari dan Cinde Adia Diningsih dalam penelitiannya menemukan bahwa pembelajaran menulis cerpen menggunakan model picture and picture dapat meningkatkan keterampilan menulis siswa (Puspitasari and Cinde Adia Diningsih), sedangkan menurut penelitian. Temuan lain yang bias dikemukakan yaitu yang dilakukan oleh A Hamzah Fansury dan Restu Januarty. Menurut mereka bahwa Model Pembelajaran Picture nd Picture dengan Media Games Android sangat menarik untuk diterapkan dalam proses pembelajaran Model Pembelajaran Picture and Picture dengan Media Games Android dapat membantu mahasiswa mengembangkan kemampuan kosa kata. Model Pembelajaran Picture and Picture dengan Media Games Android sangat efektif untuk diterapkan untuk menghindari kejenuhan dan kebosanan mahasiswa dalam mengikuti proses pembelajaran (Fansury and Januarty). Sedangkan menurut Ni Made Dwi Handayani, dkk. bahwa penerapan model Picture and Picture berpengaruh terhadap kompetensi pengetahuan IPA siswa (Dwi Handayani et al.). Hal yang lain seperti diakemukakan oleh Hendri Kuswanto dkk. ada perbedaan yang signifikan nilai posttes kelas yang diberikan perlakuan menggunakan model pembelajaran kooperatif tipe pitcure and pitcure, dan kelas yang diajar menggunakan model konvensional (Kuswanto et al.).

Begitu juga hasil penelitian yang dilakukan oleh Nur Hilal, Anggi Pratiwi, dkk., Jamilatus Saadah, Riris Saniati, dkk.; dan Wiwik Yullyb Widyawati. Umumnya penelitian-penelitian mereka menunjukkan bahwa penggunaan picture and picture memeberikan efek positif dalam pembelajaran (Nurhilal; Pratiwi et al.; Sa'adah; Saniati et al.; dan Wiwik Yully).

Perlu dikemukakan bahwa penggunaan model pembelajaran picture and picture, jika merujuk pada berbagai penelitian yang telah dikemukakan, dalam pembelajaran menulis cerita pendek diperkirakan dapat membantu peserta didik berimajinasi sesuai dengan apa yang mereka lihat langsung dalam proses pembelajaran yang akan dituangkan langsung ke dalam bentuk tulisan dan sebuh karangan yang utuh. Dengan menggunakan model pembelajaran picture and picture juga dapat meningkatkan aktivitas belajar peserta didik yang berdampak pada hasil belajar, khususnya pembelajaran bahasa Indonesia melalui materi cerita pendek.

Oleh karena itu, artikel ini akan mem-bahas bagaimana keefektifan model pem-belajaran picture and picture dalam keterampilan menulis cerpen. Hal-hal yang akan dibahas adalah (1) Bagaimanakah keefektifan model pembelajaran picture and picture dalam meningkatkan keterampilan menulis cerpen kelas XI SMK Pasundan 1 Cianjur, dan (2) Apa saja hambatan serta kendala yang ditemukan pada saat proses pembelajaran menulis cerpen dengan meng-gunakan model pembelajaran picture and picture kelas XI SMK Pasundan 1 Cianjur?

\section{METODE}

Metode yang digunakan adalah metode eksperimen yang bertujuan untuk menguji suatu model yaitu model pembelajaran picture and picture dalam keterampilan menulis cerpen. Metode eksperimen merupakan satusatunya penelitian yang benar-benar dapat menguji hipotesis mengenai hubungan sebab akibat (Sudaryono). Bentuk eksperimen yang dipilih adalah eksperimen Posttest Only Control Group Design, desain ini menjadikan populasi dibagi menjadi dua kelompok yang ditentukan secara acak. Kelompok pertama merupakan kelompok percobaan yang diberikan perlakuan, dan kelompok kedua merupakan kelompok yang tidak diberikan perlakuan (kelompok kontrol). Penelitian ini dilakukan di SMK Pasundan 1 Cianjur.

Teknik pengambilan sampel yang digunakan adalah teknik random sampling. Teknik random sampling dipilih karena setiap kelas mempunyai kesempatan yang sama (homogen). Teknik yang digunakan adalah teknik 
pengundian, hasil dari pengundian tersebut maka ditentukan XI AP 3 sebagai kelas eksperimen yang berjumlah 44 orang peserta didik, dan XI TKJ 2 sebagai kelas kontrol yang berjumlah 44 orang peserta didik.

Untuk mendapatkan hasil cerpen peserta didik, dan mengetahui apa saja hambatan dalam penerapan model pembelajaran picture and picture maka membutuhkan intrumen. Intrumen yang digunakan adalah 1. Lembar tes yang diberikan kepada peserta didik, dan melakukan tes akhir (posttest) yang bertujuan untuk mengetahui apakah ada peningkatan dari hasil belajar peserta didik sesudah menggunakan model picture and picture dalam menulis cerpen. 2. Lembar angket berupa angket tertutup (jawaban disediakan oleh pembuat angket) pertanyaan tentang faktor penunjang dan penghambat yang dialami peserta didik dalam menulis cerpen yang disampaikan langsung dengan penerapan model picture and picture. Adapun pemberian angket dilakukan setelah pelaksanaan pembelajaran berlangsung, sehingga peserta didik memperoleh pengalaman dalam menulis cerpen tersebut.

Prosedur yang digunakan sebagai berikut. Pertama, tahap praeksperimen melakukan beberapa tindakan sebagai langkah awal yang sangat penting. Menentukan dua kelas yang terdiri dari kelas eksperimen dan kelas kontrol sebagai sampel penelitian. Cara pengambilan sampel yaitu menggunakan cara random sampling. Setelah dua kelas itu terbentuk, langkah berikutnya yaitu melakukan posttest terhadap masing-masing kelas. Kedua, tahap eksperimen selanjutnya diadakan treatment (perlakuan) untuk mengetahui kemampuan menulis cerpen. Perlakuan yang dilakukan dengan menggunakan model pembelajaran picture and picture. Pemberian perlakuan dengan menggunakan model pembelajaran picture and picture terhadap kelas eksperimen, dan peserta didik berperan sebagai sasarannya. Pada kelas eksperimen, peserta didik yang menggunakan model pembelajaran picture and picture dapat mengembangkan sendiri konsep, dan fakta yang diperoleh dari hasil pengamatan gambar yang tertempel dipapan tulis atau yang ditampilkan melalui tampilan power point. Sementara itu, pada kelas kontrol peserta didik mendapatkan pembelajaran menulis cerpen secara konvensional (tanpa menggunakan model apapun). Ketiga, ahap sesudah eksperimen merupakan tahap terakhir dari proses penelitian ini. Setelah kelas kontrol dan kelas eksperimen diberi tindakan masingmasing berdasarkan ketentuan, langkah berikutnya yaitu dilakukan posttest terhadap kedua kelas. Tujuan dilakukannya posttest yaitu untuk mengetahui perbedaan keterampilan menulis cerpen menggunakan model pembelajaran picture and picture. Selain itu, untuk membandingkan hasil posttest apakah ada peningkatan hasil akhir ataukah sama saja.

Aspek yang dinilai adalah penggunaan variasi diksi, dan penggunaan gaya bahasa yang terdapat dalam cerpen karya peserta didik. Setiap aspek yang dinilai tersebut akan memiliki nilai akhir sebagai penarik kesimpulan, dan setiap aspek memiliki kriteria penilaian mulai dari nilai tertinggi, sedang, dan terendah. Aspek penilaian sebagai berikut. 1. Variasi diksi $(50=$ jika ditemukan variasi diksi lebih dari 10 kata, 35 jika ditemukan variasi diksi 5 - 9 kata, 15 = jika ditemukan variasi diksi kurang dari 5 kata). 2. Variasi gaya bahasa $(50=$ jika ditemukan variasi gaya bahasa lebih dari 3 kalimat, $35=$ jika ditemukan variasi gaya bahasa 2 - 3 kalimat, 15 = jika ditemukan variasi gaya 1 kalimat). Hasil penilaian menulis cerpen dapat dideskripsikan dan dianalisa menggunakan aplikasi SPSS 24, penggunaan aplikasi SPSS 24 adalah utnuk melakukan uji normalitas, uji homogenitas, uji Mann-Whitney, dan uji pembeda dua rata-rata Indefendent Sample TTest.

\section{HASIL DAN PEMBAHASAN}

Pembelajaran menulis cerpen dengan menggunakan model pembelajaran picture and picture yang merupakan model yang mampu meningkatkan motivasi menulis peserta didik. Hal itu, sejalan dengan penelitian 
yang telah dilakukan oleh A. Tenri Dikmaliyani Sul (2018) ditemukan keefektifan yang sama dalam penggunaan model, dan adanya peningkatan terhadap nilai-nilai yang didapatkan dari sampel (Sul).

Selain itu, hasil penelitian juga relevan dengan temuan penelitian lain, yang menjelaskan bahwa penggunaan media gambar ternyata dapat meningkatkan antusiasme siswa dalam pembelajaran dan membuat siswa lebih menyenangi pembelajaran (Nurhayati). Tingkatan keefektifan penggunaan model pembelajaran picture and picture menghasilkan nilai tertinggi $85-100$ berjumlah 9 orang, nilai 75-84 berjumlah 18 orang, nilai 55-74 berjumlah 3 orang, dan nilai 25-54 tidak ada. Sehingga dapat diakumulasikan semua jumlah nilai dengan rata-rata $82 \%$, dan jumlah peserta didik 30 orang.

Sebelum menentukan hasil akhir dari kedua kelas, maka dilakukan tahap persiapan terlebih dahulu. Persiapan dilakukan sebelum kegiatan belajar mengajar. Persiapan pembelajaran adalah acuan dalam melaksanakan kegiatan pembelajaran, adapun hal-hal yang perlu dipersiapkan selanjutnya untuk diaplikasikan dalam pembelajaran. Persiapan pembelajaran dalam bentuk silabus, dan rencana pelaksanaan pembelajaran (RPP). Silabus dan RPP dikembangkan dari kurikulum yang berlaku. Silabus dan RPP yang disajikan dalam penelitian ini mengenai pembelajaran menulis cerpen dengan menggunakan model pembelajaran picture and picture di kelas XI SMK Pasundan 1 Cianjur.

Selanjutnya, untuk mengetahui keefektifan model pembelajaran picture and picture dalam keterampilan menulis cerpen, maka dilakukan tes kepada peserta didik, dan untuk mengetahui hambatan dalam penerapan model pembelajaran picture and picture maka dilakukan penyebaran angket pada kelas eksperimen setelah model pembelajaran diberikan.
Hasil penilaian posttest pada kelas eksperimen menghasilkan jumlah rata-rata 72,38. Nilai rata-rata tertinggi dihasilkan pada aspek variasi diksi yang jumlah rata-ratanya adalah 48,63. Nilai rata-rata terendah dihasilkan pada aspek variasi gaya bahasa yaitu dengan nilai 23,40. Untuk lebih jelasnya dapat diperhatikan grafik berikut.

Nilai Posttest Kelas Eksperimen

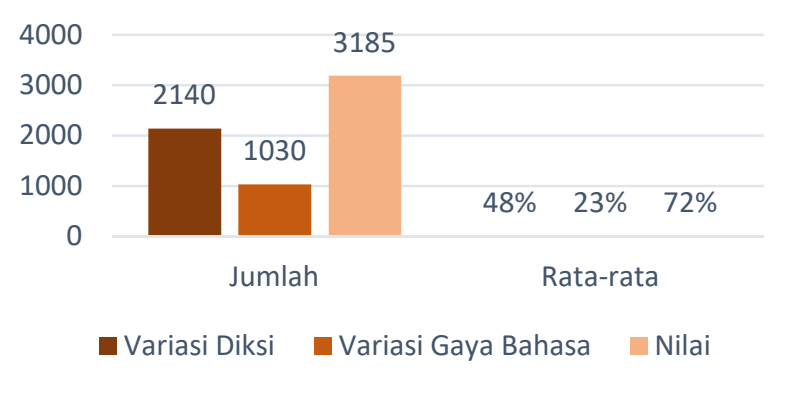

Hasil penilaian posttest pada kelas kontrol menghasilkan jumlah rata-rata 64,43. Nilai rata-rata tertinggi dihasilkan pada aspek variasi diksi yang jumlah rata-ratanya adalah 46,25 . Nilai rata-rata terendah dihasilkan pada aspek variasi gaya bahasa yaitu dengan nilai 18,18 . Untuk lebih jelasnya dapat diperhatikan grafik berikut.

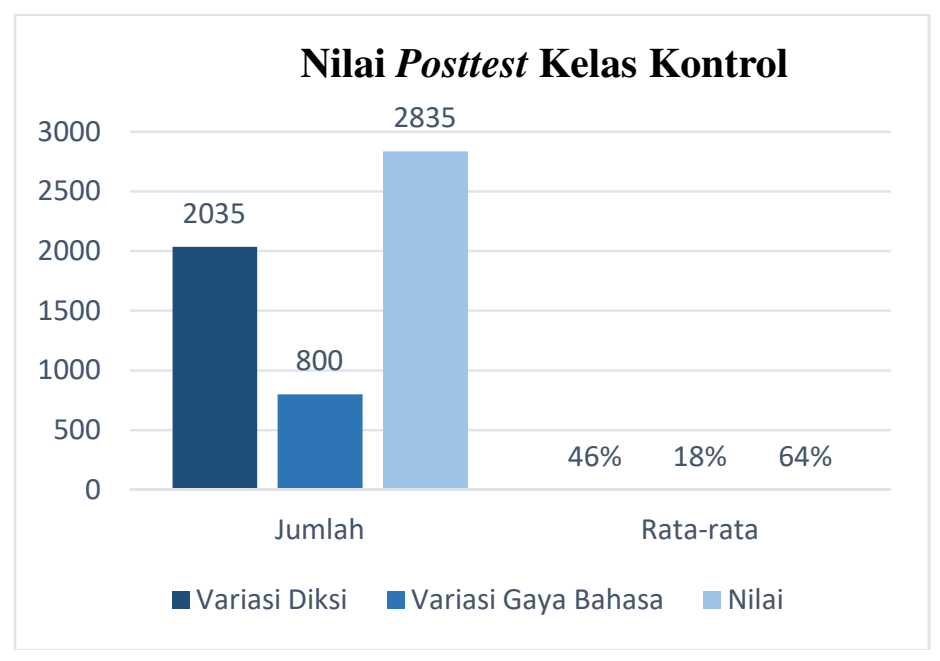

Temuan variasi diksi dan gaya bahasa, dalam proses pembelajaran menulis cerpen dengan menggunakan model pembelajaran picture and picture pelaksanaan pembelajaran mengacu pada silabus dan RPP yang telah disusun. Langkah-langkah pembelajatan model picture and picture meliputi kegiatan pendahuluan, inti, dan penutup. 
Berdasarkan hasil analisis variasi diksi, dan gaya bahasa pada posttest dari 44 peserta didik kelas eksperimen penguasaan penggunaan variasi diksi berjumlah $350 \mathrm{kata}$, dan penggunaan gaya bahasa berjumlah 100 kalimat. Sedangkan pada posttest kelas kontrol dari 44 peserta didik penguasaan penggunaan variasi diksi berjumlah 150 kata, dan penggunaan gaya bahasa berjumlah 83 kalimat. Dari data tersebut, penggunaan variasi diksi, dan gaya bahasa dari kedua kelas tidak jauh berbeda dengan selisih penggunaan variasi diksi 200 kata, dan penggunaan gaya bahasa selisih 17 kalimat. Oleh karena itu, dapat diperoleh kesimpulan dari hasil analisis posttest peserta didik sangat mudah menambah karena penggunaan model pembelajaran picture and picture.

Berdasarkan hasil tes dari 8 varisi diksi yang sering muncul diantaranya diksi sinonim yaitu (laki-laki=pria, wanita=perempuan, tunggal=satu, pahit=getir, bapak=ayah), diksi antonim yaitu (masuk=keluar, panik=diam, hidup=mati, positif=negatif), diksi polisemi yaitu (kepala, memeluk, tangani), diksi hipernim yaitu (tas, hewan, kendaraan), diksi hiponim yaitu (motor, ayam, anggur), diksi homonim yaitu (bulan=satelit atau bulan dalam kalender, bagi=pembagian atau untuk, rapat=tidak renggang atau pertemuan), diksi homofon yaitu (massa= kerumunan warga, masa=waktu), diksi homograf yaitu (bisa=mampu atau racun ular, serang=nama kota atau perang). Sedangkan hasil tes dari 12 variasi gaya bahasa yang muncul diantaranya metafora contoh (kupukupu malam itu sedang mencari mangsa= pelacur), personifikasi contoh (angin berbisik membelai raga), hiperbola contoh (tangisnya menyayat hatiku), sinisme contoh (cantiknya bagaikan rembulan dimalam hari).

Uji hipotesis keefektifan model pembelajaran picture and picture dalam menulis cerpen. Pada bagian ini akan dipaparkan mengenai keefektifan model pembelajaran picture and picture dalam keterampilan menulis cerpen melalui program SPSS 24. Analisis data hasil tes akhir (posttest), tujuan diberikan posttest adalah untuk mengetahui apakah kelas eksperimen dan kelas kontrol memiliki kemampuan akhir yang berbeda atau sama setelah melakukan pembelajaran dengan menggunakan model yang berbeda. Berikut ini adalah deskripsi statistik yang dihasilkan dari data posttest baik kelas eksperimen maupun kelas kontrol. Analisis yang dihasilkan dari data posttest baik kelas eksperimen maupun kelas kontrol sebagai berikut.

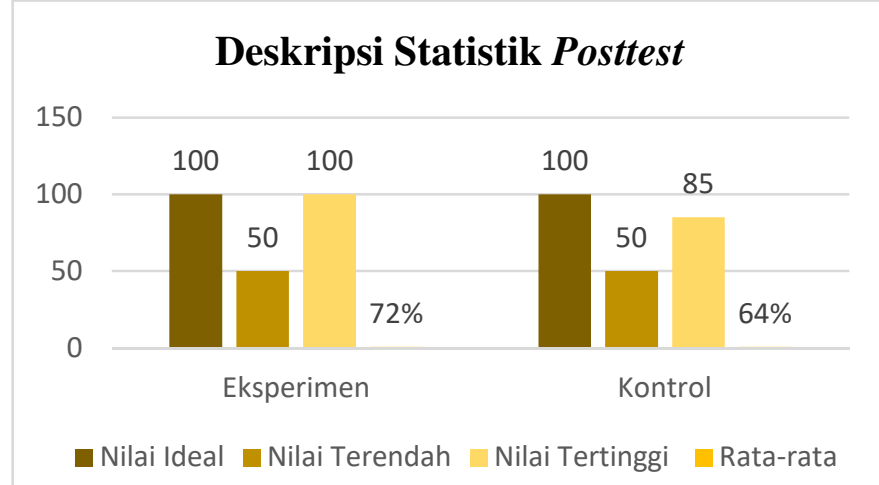

Hambatan-hambatan yang dialami peserta didik dalam menulis cerpen. Ber-dasarkan hasil penelitian, terdapat faktor-faktor yang menjadi penghambat bagi peserta didik dalam menulis cerpen. 1. Pada proses pembelajaran peserta didik kesulitan dalam menuangkan ide ke dalam tulisan. Hal tersebut terjadi karena kurang memadainya kemam-puan berbahasa, dan kurangnya pengetahuan tentang kaidahkaidah kebahasaan menulis. 2. Peserta didik kesulitan dalam mencari atau memilih kata (diksi) dan gaya bahasa yang tepat untuk dikembangkan dalam sebuah tulisan, hal ini terbukti dari $18 \%$ peserta didik masih mengalami hambatan dalam menulis cerpen.

Untuk mendapatkan data tentang materi cerpen, maka dilakukan penyebaran angket kepada 44 peserta didik di kelas eksperimen. Hasilnya akan disusun dalam bentuk tabel, data akhir angket akan dijadikan sebagai bahan kajian kesimpulan. Analisis angket dapat adalah sebagai berikut.

Pada aspek minat nomor 1 dari 44 peserta didik $82 \%$ peserta didik menyukai pelajaran bahasa Indonesia, aspek minat nomor 2 dari 44 peserta didik $43 \%$ menyukai pembelajaran menulis, dan aspek minat nomor 
4 dari 44 peserta didik $68 \%$ menyukai pembelajaran cerpen. Pada aspek kesulitan nomor 3 dari 44 peserta didik 39\% mengalami kesulitan saat menulis cerpen, pada aspek kesulitan nomor 6 dari 44 peserta didik $61 \%$ berpendapat bahwa menulis cerpen itu sulit karena terkadang tidak ada ide dan biasanya dalam keadaan malas untuk menulis, pada aspek kesulitan nomor 9 dari 44 peserta didik 48\% merasa kesulitan saat menulis melalui model picture and picture, karena model ini baru mereka pelajari dan dapatkan, sehingga masih merasa kesulitan untuk mengurutkan setiap ide sesuai dengan urutan gambar. Pada aspek menulis cerpen nomor 5 dari 44 peserta didik $77 \%$ pernah menulis sebuah cerpen walaupun masih belajar, pada aspek menulis cerpen nomor 7 dari 44 peserta didik $80 \%$ bahwa pembelajaran menulis cerpen itu menarik, karena dapat mencurahkan perasaan yang sedang dialami, dan pada aspek menulis cerpen nomor 8 dari 44 peserta didik $86 \%$ peserta didik telah mendapatkan pelajaran menulis cerpen. Pada aspek terakhir nomor 10 yaitu model pembelajaran picture and picture dari 44 peserta didik $73 \%$ merasakan bahwa model picture and picture mempermudah

\begin{tabular}{cccc}
$N$-Gain & \multicolumn{3}{c}{ Kelas Eksperimen } \\
$N$-gain $\geq 0,70$ & 10 & Tinterpretasi & $\%$ \\
$0,30<N$-gain $<$ & 25 & Sedang & $23 \%$ \\
0,70 & & Rendah & $20 \%$
\end{tabular}

dalam menulis, dan dianggap menarik dalam kegiatan menulis cerpen.

Jadi pembelajaran materi cerpen melalui model pembelajaran picture and picture sangat cocok, dapat diketahui dengan jumlah jawaban angket yang telah disebarkan kepada peserta didik hampir $73 \%$ merasakan bahwa model picture and picture mempermudah dalam menulis, dan dianggap menarik dalam kegiatan menulis cerpen.

Pembahasan efektivitas model pembelajaran picture and picture, kegiatan belajar mengajar peserta didik berperan aktif dan bersikap positif menerima pembelajaran. Dilihat dari hasil angket $73 \%$ peserta didik mampu merasakan bahwa model picture and picture mempermudah dalam menulis, dan dianggap menarik dalam kegiatan menulis cerpen. Proses pembelajaran yang dilakukan cukup efektif, karena hasil proses pembelajaran mengalami perbedaan antara kelas yang menggunakan perlakuan (treatment) dengan kelas yang tidak menggunakan perlakuan (treatment).

Jadi proses pembelajaran yang dilakukan dalam penelitian ini cukup efektif, karena hasil nilai peserta didik mengalami peningkatan dan terdapat perbedaan antara kelas eksperimen yang diberikan perlakuan (treatment) dengan hasil nilai (posttest) 72,38. Sedangkan kelas kontrol yang tidak diberikan perlakuan (treatment) manghasilkan nilai (posttest) 64,43, dari hasil tes kedua kelas terdapat selisih nilai 7,95. Jumlah peningkatan kemampuan menulis cerpen pada kelas kontrol dan kelas eksperimen dapat dibuktikan pada tabel berikut.

\section{Tabel 1: Jumlah Peningkatan Kemampuan Menulis Cerpen Melalui Model Picture and Picture}

$\begin{array}{ccc}\text { Jumlah } & \text { Kelas Kontrol } & \\ 7 & \text { Interpretasi } & \% \\ 22 & \text { Tinggi } & 16 \% \\ 15 & \text { Sedang } & 50 \% \\ & \text { Rendah } & 34 \%\end{array}$

Hasil uji n-gain pada kelas eksperimen ada 10 orang yang memiliki kemampuan menulis tinggi, 25 orang dengan nilai kemampuan menulis sedang, dan ada 9 orang yang memiliki kemampuan menulis rendah. Sedangkan pada kelas kontrol ada 7 orang yang memiliki kemampuan menulis tinggi, 22 orang dengan nilai kemampuan menulis

\section{Hasil Uji N-gain Jumlah Peningkatan Kemampuan Menulis Cerpen}

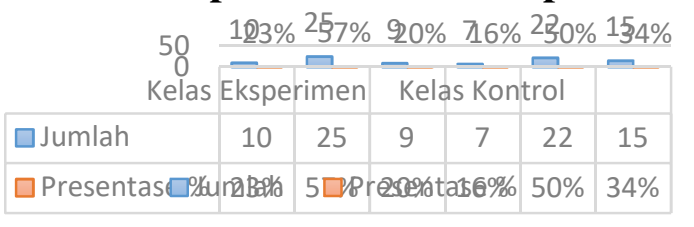


sedang, dan ada 15 orang yang memiliki kemampuan menulis rendah. Hal tersebut dapat dipengaruhi ketika menulis cerpen, penggunaan diksi dan gaya bahasanya yang kurang bervariatif.

Keefektifan penggunaan model pembelajaran picture and picture dapat meningkatkan keterampilan menulis cerpen, hal ini terbukti dari hasil data uji normalitas, rata-rata skor posttest pada kelas eksperimen dan kelas kontrol, dan melakukan uji Indefendent Sampel T-Test. Skor rata-rata posttest yang diperoleh kelas eksperimen adalah 72,38, sedangkan rata-rata yang diperoleh kelas kontrol adalah 64,43. Dari rata-rata tersebut terlihat bahwa kemampuan menulis cerpen pada kelas eksperimen lebih besar dibandingkan kelas kontrol, dengan selisih 7,95 .

Pada kelas eksperimen ada 10 orang yang memiliki kemampuan menulis tinggi, 25 orang dengan nilai kemampuan menulis sedang, dan ada 9 orang yang memiliki kemampuan menulis rendah. Sedangkan pada kelas kontrol ada 7 orang yang memiliki kemampuan menulis tinggi, 22 orang dengan nilai kemampuan menulis sedang, dan ada 15 orang yang memiliki kemampuan menulis rendah. Kemampuan menulis rendah tersebut dapat dipengaruhi ketika peserta didik menulis cerpen, terdapat penggunaan diksi dan gaya bahasanya yang kurang bervariatif. Dengan demikian, hipotesis yang diajukan "Keefektifan Model Pembelajaran Picture and Picture dalam Keterampilan Menulis Cerpen di Kelas XI" dapat diterima, karena dengan menggunakan model pembelajaran picture and picture terdapat meningkatkan keterampilan peserta didik dalam menulis cerpen.

Peningkatan terjadi karena adanya keefektifan dari model picture and picture sebab model ini mudah dipahami oleh sampel dan memudahkan dalam proses pembelajaran yang diberikan. Seperti yang dikemukakan oleh Soedijarto dalam Kamalawati (2015:66) menyatakan bahwa peranan pendidik sebagai pengelola proses pembelajaran sangat menentukan kualitas proses belajar, yang pada akhirnya akan bermuara pada kualitas hasil pembelajaran (Kamalawati).

Penelitian lain yang mendukung, ditemukan hasil penelitian Sul (2018:6) ditemukan keefektifan yang sama dalam penggunaan model, dan adanya peningkatan terhadap nilainilai yang didapatkan dari sampel. Tingkatan keefektifan penggunaan model pembelajaran picture and picture menghasilkan nilai tertinggi 85-100 berjumlah 9 orang, nilai 7584 berjumlah 18 orang, nilai 55-74 berjumlah 3 orang, dan nilai 25-54 tidak ada. Sehingga dapat diakumulasikan semua jumlah nilai dengan rata-rata $82 \%$, dan jumlah peserta didik 30 orang. Gambaran keefektifan model pembelajaran picture and picture dapat dilihat pada tabel berikut.

Tabel 2: Keefektifan Model Pembelajaran Picture And Picture

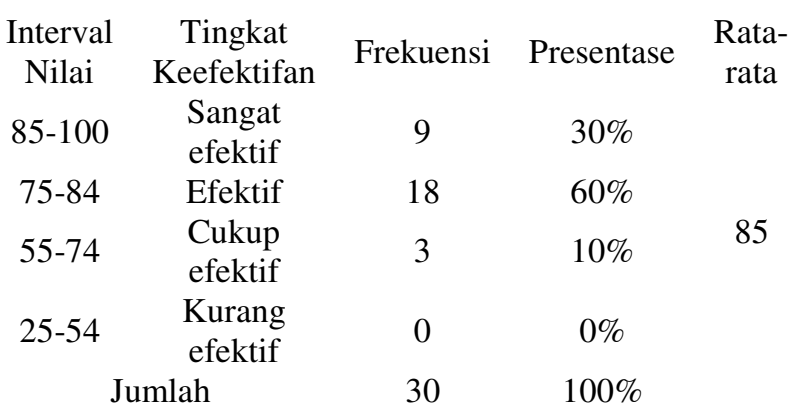

\section{PENUTUP}

Berdasarkan hasil penelitian yang telah dilaksanakan pada tanggal 28 Januari sampai 28 Maret 2019, mengenai keefektifan model pembelajaran picture and picture dalam pembelajaran menulis cerpen di kelas XI SMK Pasundan 1 Cianjur, dapat disimpulkan sebagai berikut.

Persiapan pembelajaran dalam penelitian dijadikan acuan dalam melaksanakan pembelajaran. Segala sesuatu yang disajikan dalam persiapan selanjutnya diaplikasikan dalam pembelajaran. Persiapan pemebelajaran disajikan berupa silabus dan rencana pelak-sanaan 
pembelajaran (RPP) yang berkaitan dengan materi cerpen. Langkah-langkah pembelajaran meliputi kegiatan pendahuluan, inti, dan penutup. Adapun penerapan model pembelajaran picture and picture diterapkan dalam kegiatan inti. Penerapan model pembelajaran dapat dikatakan cukup berhasil diterapkan pada peserta didik,

Berdasarkan hasil penelitian, terdapat beberapa faktor yang menghambat peserta didik dalam menulis cerpen. Di antaranya: pada proses pembelajaran umumnya peserta didik kesulitan dalam menuangkan gagasan atau ide ke dalam sebuah tulisan, hal tersebut terjadi karena kurang memadainnya kemampuan berbahasa. Selain itu peserta didik sulit dalam mencari, memilih kata yang tepat untuk dijadikan sebuah tulisan atau kalimat. Untuk memberikan sebuah penilaian terhadap hasil menulis cerpen, disusunlah kriteria penilaian yaitu penggunaan variasi diksi, dan penggunaan variasi gaya bahasa. Dari kriteria penilaian tersebut dapat diketahui sejauh mana pengusaan bahasa dan pemilihan kata yang tepat pada cerpen yang dibuat oleh setiap peserta didik.

Hal yang tidak kalah pentingnya adalah cerita pendek yang dihasilkan, dijadikan bagian dari sebuah penilaian, yakni sebagai bagian dari portofolio siswa dalam pembelajaran secara keseluruhan karena portofolio menurut Mulyadi, merupakan penilaian berkelanjutan yang didasarkan pada kumpulan informasi yang menunjukan perkembangan kemampuan murid dalam satu periode tertentu. Informasi perkembangan murid tersebut dapat berupa karya murid (hasil pekerjaan, dari proses pembelajaran yang dianggap terbaik oleh muridnya), hasil tes (bukan nilai), piagam penghargaan atau bentuk informasi lain yang terkait dengan kompetensi tertentu dalam satu mata pelajaran (Ferdiana and Pamungkas).

Semoga tulisan ini dapat bermanfaat bagi semua pihak terutama guru dan peneliti yang akan datang. Dengan adanya peningkatan hasil belajar yang lebih baik, maka model pembelajaran picture and picture dapat dijadikan salah satu alternatif dalam pembelajaran cerpen. Sehingga peserta didik merasa senang dan termotivasi dalam proses pembelajaran bahasa Indonesia.

Hendaknya penelitian sejenis dilakukan dengan model yang berbeda, atau dengan model pembelajaran yang lainnya. Hal tersebut dilakukan untuk menguji efektifitas model pembelajaran yang akan dilakukan, dan sesuai dengan materi ajar. Bukan hanya model pembelajaran picture and picture yang dapat mempengaruhi hasil belajar peserta didik, maka perlu adanya penelitian lebih lanjut tentang faktor penunjang lainnya, sehingga mempengaruhi hasil belajar peserta didik. Perlu benar-benar paham bagaimana prosedur yang benar dalam menggunakan model pembelajaran picture and picture.

Selain itu, lebih kreatif memilih model atau pendekatan pembelajaran, media pembelajaran, dan sumber belajar agar peserta didik tidak merasa bosan pada saat kegiatan pembelajaran berlangsung.

\section{DAFTAR PUSTAKA}

Dalman. Keterampilan Menulis. PT Taja Grafindo Persada, 2014.

Dwi Handayani, Ni Made, et al. "Model Pembelajaran Picture and Picture Berbantuan Media Audio-Visual Terhadap Kompetensi Pengetahuan Ipa.” Journal of Education Technology, vol. 1, no. 3, 2017, p. 176, doi:10.23887/jet.v1i3.12502.

Fansury, A. Hamzah, and Restu Januarty. "Model Pembelajaran Picture and Picture Dengan Media Games Android Dalam Meningkatkan Kemampuan Kosa Kata Siswa Kelas VII SMPN 35 MAKASSAR.” Jurnal Keguruan Dan Ilmu Pendidikan, vol. 4, no. 1, 2017, pp. 73-85. 
Ferdiana, M. Dian, and Daud Pamungkas. "Penggunaan Penilaian Berbasis Kelas Dan Portofolio Dalam Menumbuhkan Minat Baca." Alinea: Jurnal Bahasa, Sastra, Dan Pengajaran, vol. 8, no. 2, 2019, pp. 87-98.

Kamalawati, S. N. A. Penerapan Pendekatan Saintifik Bagi Peningkatan Kemampuan Menulis Cerita Pendek Di Kelas VII SMP Negeri 2 Cianjur Tahun Ajar 2014-2015. 2015.

Kuswanto, Hendri, et al. "Efektivitas Model Pembelajaran Picture And Picture Terhadap Hasil Belajar Siswa IPS.” JPG (Jurnal Penelitian Geografi), vol. 5, no. 1, 2017, pp. 2-11.

Nurhilal. "Penerapan Model Pembelajaran Picture and Picture Dalam Meningkatkan Hasil Belajar PKn.” Jurnal Global Edukasi, vol. I, no. 3, 2017, pp. 430 - 433.

Pratiwi, Anggi, et al. "Efektivitas Penggunaan Model Picture and Picture Dalam Pembelajaran Menulis Teks Berita Siswa Kelas VIII/B MTS Negeri Sijenjang Kota Jambi Tahun Ajaran 2016/2017." Jurnal Ilmiah Pendidikan Bahasa Dan Sastra Indonesia, vol. 1, no. 2, 2018, pp. 84-91, http://aksara.unbari.ac.id/index.php/aksara/article/view/37.

Puspitasari, Nur, and Cinde Adia Diningsih. "Using Picture And Picture Model To Improve Writting Short Story." Alinea: Jurnal Bahasa, Sastra, Dan Pengajaran, vol. 7, no. 2, 2018, pp. 112-19, doi:10.35194/alinea.v1i3.407.

Sa'adah, Jamilatus. 'Metode Pembelajaran 'Picture and Picture' Dalam Menulis Teks Cerita Fiksi Novel Pada Buku Teks Bahasa Indonesia Ekspresi Diri Dan Akademik SMA/MA/SMK/MAK Kelas X11 Semester 2 Kurikulum 2013.” Bahastra, vol. 37, no. 1, 2017, p. 45, doi:10.26555/bahastra.v37i1.5958.

Saniati, Riris, et al. "Pengaruh Model Pembelajaran Picture And Picture Dalam Menulis Cerpen Pada Siswa Kelas XI SMK Negeri 1 Puring Kabupaten Kebumen Tahun Ajaran 2017/2018." Surya Bahtera, vol. 6, no. 50, 2018, pp. 79-86, http://ejournal.umpwr.ac.id/index.php/surya-bahtera/article/viewFile/5218/4768.

Sudaryono. Metodologi Penelitian. Raja Grafindo Persada, 2017.

Sul, A. Tenri Dikmaliyani. Keefektifan Penggunaan Model Picture and Picture Terhadap Hasil Pembelajaran Menulis Cerpen Siswa Kelas XI SMK Negeri 4 Makassar. Universitas Negeri Makasar, 2018, http://eprints.unm.ac.id/11954/.

Sumardjo, Jakob. Menulis Cerpen. Pustaka Pelajar, 2007.

Wiwik Yully, Widyawati. "Keefektifan Model Pembelajaran Picture and Picture Dalam Keterampilan Menulis Untuk Tingkat Universitas.” Jurnal Kredo, vol. 2, no. 2, 2019, pp. $226-41$. 